\title{
Coconut oil on biochemical and morphological parameters in rats submitted to normolipidic and hyperlipidic diets
}

\author{
Óleo de coco em parâmetros bioquímicos e morfológicos de ratos submetidos \\ à dieta normolipídica ou hiperlipídica
}

\author{
Bianca de Oliveira Schumacher ${ }^{\mathrm{I}}$ Edcarlos Maurino Preuss ${ }^{\mathrm{I}}$ \\ Carolina Galarza Vargas ${ }^{\text {II }}$ Elizabete HelbigI ${ }^{\text {* }^{*}}$
}

\section{ABSTRACT}

This study aimed to evaluate the influence of replacing soybean oil with extra virgin coconut oil in normolipidic and hyperlipidic diets, on the lipid metabolism of Wistar rats. In the first stage of the experiment (30 days), 36 rats were divided into 2 groups and fed with a control or a hyperlipidic diet. Six animals from each group were then killed, and the remaining rats were redistributed into 4 new groups: 2 groups remained on the control and hyperlipidic diets, and in the diets of the other 2 groups, the soybean oil was replaced with coconut oil (30 days). At the end of the assay, the biological models were decapitated for blood collection and removal of organs and peritoneal fat. Although the diet intake differed among groups during both stages of the experiment, no differences were noted with regard to weight gain and peritoneal fat. Replacing soybean oil with coconut oil in the rat diet lowered triglyceride and low-density lipoprotein serum concentrations in both groups. Liver parameters, namely, total cholesterol and triacylglycerols, increased with the substitution of soybean oil by coconut oil in the normolipidic diet and decreased in the hyperlipidic diet. Thus, replacing soybean oil by coconut oil may improve serum and liver lipid levels in Wistar rats.

Key words: Cocos nucifera L., extra virgin coconut oil, obesity, rat, diet.

RESUMO

O estudo teve como objetivo avaliar a influência da substituição do óleo de soja por óleo de coco extravirgem em dietas normolipídicas e hiperlipídicas, sobre o metabolismo lipídico de ratos Wistar. Na primeira fase do experimento, 30 dias, 36 ratos foram distribuidos em dois grupos, receberam dieta controle e dieta hiperlipídica. Após eutanásia de seis animais por grupo, os ratos de ambos os grupos foram redistribuidos em quatro novos grupos, dois permaneceram com as dietas controle e hiperlipídica e nos outros dois houve substituição do óleo de soja por óleo de coco (30 dias). Ao final do ensaio, os modelos biológicos foram decapitados, para coleta de sangue, retirada de órgãos e gordura peritoneal. O consumo de dieta foi diferente entre os grupos durante as duas fases do experimento, porém sem diferença no ganho de peso e gordura peritoneal. A substituição, na dieta, do óleo de soja por óleo de coco diminuiu as concentrações séricas de triacilgliceróis e de lipoproteinas de baixa densidade, em ambos os grupos. Os parâmetros hepáticos colesterol total e triacilgliceróis aumentaram com a substituição do óleo de soja por óleo de coco em dieta normolipídica e diminuíram na dieta hiperlipídica. A substituição do óleo de soja por óleo de coco pode ter benefícios com relação aos lipídeos séricos e hepáticos em ratos Wistar.

Palavras-chave: Cocos Nucifera L., óleo de coco extravirgem, obesidade, rato, dieta.

\section{INTRODUCTION}

Obesity is a chronic condition characterized by excessive accumulation of body fat, resulting from a positive energy balance, which compromises health (WHO, 2003). In the Brazilian population, although there has been a decrease in sub-nutrition among children and adults, an increase has been noted in the prevalence of overweight and obese people (FILHO \& RISSIN, 2003). Nutritional transition is one of the factors that contribute to the rise of this epidemic, i.e. the increase in dietary energy supply and reduction in physical activity, which can be characterized as the contemporary western lifestyle (KUMANYAKA, 2001; WHO, 2003).

\footnotetext{
'Departamento de Nutrição, Faculdade de Nutrição, Universidade Federal de Pelotas (UFPEL), Pelotas, RS, Brasil.

"Programa de Pós-graduação Nutrição e Alimentos, Departamento de Nutrição, Faculdade de Nutrição, Universidade Federal de Pelotas
} (UFPEL), 96010-610, Pelotas, RS, Brasil. E-mail: helbignt@gmail.com. "Corresponding author. 
Western diet has been associated with dyslipidaemias as a large portion of the energy in this diet is derived from saturated fat, usually of animal origin. The regular intake of this type of fat tends to increase the levels of total cholesterol (TC), lowdensity lipoprotein (LDL), and triacylglycerols (TAGs) (AHA, 2000). Lipids are important components of the human diet because of their nutritional, functional, and sensory properties. They are vital for complete metabolism in an organism, since they provide the essential fatty acids that are the structural components of cell membranes and prostaglandins, in addition to their role as carriers for the liposoluble vitamins A, D, E, and K (PEREDA et al., 2005).

Saturated fats are classified as short, medium, long, and extra-long based on the length of their carbon chains. Medium-chain fatty acids (MCFAs) are mainly found in coconut oil. TAGs rich in MCFAs (MCTs) constitute an immediate energy source much like carbohydrates and have a low tendency to incorporate into the adipose tissue (ASAKURA et al., 2000).

Because of their chain length, MCTs are not metabolized in the intestines. After their hydrolysis during the first phase of digestion, MCTs are absorbed as essential fatty acids and transported directly to the liver, where they are oxidized to provide energy, increasing thermogenesis and energy expenditure. Long chain fatty acids (chylomicrons and very low-density lipoproteins (VLDLs)) require lipoprotein carriers, resulting in an increase in their levels in the serum (ASAKURA et al., 2000).

Because of the increase in the occurrence of overweight and obese people, it has become necessary to utilize fat sources that are fast acting and have low storage rates, such as that in coconut oil. Coconut is the fruit of the palm tree Cocos nucifera (known as "coco-da-baía" in Brazil) that grows in tropical regions and is cultivated in more than 80 countries worldwide. Coconut is known as a source of oil, with various industrial and culinary applications. Brazil is a large producer of coconut; however, it only utilizes it as a fruit in natura, and its "derivatives" in the form of condiments and seasonings (BAWALAN \& CHAPMAN, 2006).

Only few studies are available on extra virgin coconut oil. The size, level of saturation, and positional distribution of fatty acids in TAGs derived from the diet are known to have important effects on cell lipids and lipaemia, whereby this food source could improve the health of the individual (ALMEIDA et al., 2009). In the present study, we aimed to evaluate whether replacing soybean oil with extra virgin coconut oil in normolipidic and hyperlipidic diets influences lipid metabolism in Wistar rats.

\section{MATERIALS AND METHODS}

Thirty-six, 60-day-old (300-360g) male rats, belonging to the Wistar breed (Rattus norvegicus) were used in this study; the rats were maintained at the Central Animal House of the Universidade Federal de Pelotas (UFPEL), and were randomly allocated to individual metallic cages inside ventilated rooms with temperature and relative humidity of $22-24^{\circ} \mathrm{C}$ and $65-75 \%$, respectively, and a 12-h light:dark cycle.

The bioassay lasted 70 days and was carried out in two stages, both including 5 days of adaptation followed by 30 experimental days. In the first stage, the biological models $(n=36)$ were divided into two groups, with 18 being fed with an AIN-93M control diet (4\% soybean oil: CDSO) and the remaining 18 , with a hyperlipidic diet $(4 \%$ soybean oil $+12 \%$ pork lard: HDPL). Normolipidic and hyperlipidic diets were used in the first stage in order to test the effects of coconut oil treatment in the second stage. After 30 days, 6 rats from each group $(n=12)$ were killed by decapitation.

The second stage of the experiment consisted of coconut oil treatment; the rats were allowed to first adapt to the new diet. The 12 rats fed with the control diet (CDSO) were randomly split into 2 groups, with one group continuing with the control diet and the other receiving a diet in which the lipid source was replaced with coconut oil at $4 \%$ (DTCO). The 12 rats on hyperlipidic diet were further randomly divided into two groups, of which one group remained on the hyperlipidic diet (HDPL) and the other received a hyperlipidic diet in which the pork lard $(12 \%)$ was retained and the soybean oil was replaced with coconut oil (4\%) (HDCO). The rats were provided with water and food ad libitum. Weight gain and diet intake were monitored during the bioassay. At the end of each stage, the rats were left to fast for a period of $12 \mathrm{~h}$ and then decapitated. All procedures were performed according to resolution no. 714 of the Council of Veterinary Medicine (CFMV), June 2002, following the Ethical Principles for Animal Experimentation adopted by the Brazilian College for Animal Experimentation (COBEA, 2012). This study was approved by CEEA/UFPEL (5250).

Four diets have been described above and their compositions are based on the formulation recommended by the American Institute of Nutrition AIN-93M (REEVES et al., 1993). The method by 
BLIGH \& DYER (1959) was used for lipid analysis, and protein, ash, fibre, and humidity levels were analysed according to the methodologies described by the Association of Official Analytical Chemists (AOAC, 1995). The analyses were performed in triplicate and expressed on a dry matter basis.

TC, high-density lipoprotein (HDL), and TAG in the serum were determined using an enzymatic-colorimetric method. The concentrations of LDLs were estimated using the formula by FRIEDEWALD et al. (1972).

Statistical analysis of the data was performed by analysis of variance (ANOVA), and the means were compared using Tukey's test, with a 5\% level of significance for the variables analysed.

\section{RESULTS AND DISCUSSION}

The mean values of intake, weight gain, and peritoneal fat are presented in table 1. No significant difference was observed for weight gain parameter $(\mathrm{P}<0.05)$; however, diet intake showed a statistically significant difference $(\mathrm{P}<0.05)$ between the groups in the same period. The average feed intake was $17.0 \%$ lower for the HDCO group than for the CDSO group. As shown in table 1, a significant difference was noted between the groups regarding peritoneal fat $(\mathrm{P}<0.05)$, which reduced by $25.6 \%$ when coconut oil was used in the normolipidic diet and by $30.6 \%$ in the hyperlipidic diet.

Conflicting results are available in the literature regarding weight gain in rats fed hyperlipidic diets (ESTADELLA et al., 2004). According to KIM et al. (1998), high-fat diets are associated with hyperphagia, which contradicts the findings of the present study, where significant changes were observed, resulting in lower food intake among the rats in the hyperlipidic group. OSCAI \& MILLER (1987) observed no significant difference regarding food intake in rats fed with normocaloric and hypercaloric diets.
However, these findings diverge, as KRETSCHMER et al. (2005) also reported a reduction in food intake in animals fed with a high fat diet.

Even without significantly altering the weight gain, the hyperlipidic diet resulted in an increase in peritoneal fat deposition in rats over the 60 days of the experiment. These findings are similar to those by BERNARDES et al. (2004).

According to LANGE et al. (2005) and MOURA et al. (2012), the accumulation of fat in the abdominal region must be carefully monitored, as this increase is considered a determining factor in the development of insulin resistance, also because the abdominal adipose tissues are metabolically more active than the peripheral adipose tissues. After replacing soybean oil with extra virgin coconut oil in both diets, was observed a reduction in peritoneal fat and lower food intake in the hyperlipidic groups, but no significant differences were noted in the weight gain.

In their study, DEBMANDAL \& MANDAL (2011) followed the theory that MCFAs in coconut oil are easily oxidized to lipids and are not stored in the adipose tissue, unlike long-chain fatty acids (LCFAs). Considering this and the fact that coconut oil is rich in MCFAs and poor in LCFAs, the use of extra virgin coconut oil could be effective in the treatment of obesity. Conversely, POPPITT et al. (2010) evaluated the relationship between fatty acid chain length in post-meal satiation and food ingestion in lean men and concluded that there was no evidence that the length of the fatty acid chain has any effect on appetite or food ingestion.

As shown in table 2, statistically significant differences $(\mathrm{P}<0.05)$ were observed regarding the biochemical parameters, serum LDL and TAG, as well as TC and liver TAG, when the rats received diets with coconut oil. Lower LDL values were obtained following treatment with coconut oil. LDL in rats fed with DTCO-fed was $25.6 \%$ lower than that in rats fed with CDSO; further, in rats fed with hyperlipidic

Table 1 - Total dietary intake, total weight gain, and peritoneal fat in rats after experimental use of extra virgin coconut oil ( $\mathrm{n}=6$ ).

\begin{tabular}{lccc}
\hline Groups & Total dietary intake $(\mathrm{g})$ & Total weight gain $(\mathrm{g})$ & Peritoneal fat $(\mathrm{g})$ \\
\hline CDSO & $588.31 \pm 31.87^{\mathrm{a}}$ & $87.09 \pm 12.79$ & $21.10 \pm 3.62^{\mathrm{b}}$ \\
DTCO & $547.82 \pm 32.14^{\mathrm{a}, \mathrm{b}}$ & $76.79 \pm 10.57$ & $15.75 \pm 2.92^{\mathrm{b}}$ \\
HDPL & $498.32 \pm 40.43^{\mathrm{b}}$ & $83.09 \pm 8.36$ & $32.13 \pm 3.97^{\mathrm{a}}$ \\
HDCO & $488.29 \pm 34.58^{\mathrm{b}}$ & $85.22 \pm 15.28$ & $22.30 \pm 2.10^{\mathrm{b}}$ \\
\hline
\end{tabular}

Results expressed as mean \pm standard deviation ( $n=6 /$ group). Different letters in the same column indicate significant difference according to Tukey test $(\mathrm{P}<0.05)$. CDSO: control diet AIN-93M (4\% soybean oil); DTCO: normolipidic diet (4\% coconut oil); HDPL: hyperlipidic $\operatorname{diet}(4 \%$ soybean oil $+12 \%$ pork lard); HDCO: hyperlipidic diet $(4 \%$ coconut oil $+12 \%$ pork lard). 
Table 2 - Biochemical parameters evaluated in the serum of rats after experimental use of extra virgin coconut oil ( $\mathrm{n}=6)$.

\begin{tabular}{|c|c|c|c|c|}
\hline Groups & Serum TC $\left(\mathrm{mg} \cdot \mathrm{dL}^{-1}\right)$ & Serum HDL $\left(\mathrm{mg} \cdot \mathrm{dL}^{-1}\right)$ & Serum LDL $\left(\mathrm{mg}^{\mathrm{d} \mathrm{dL}^{-1}}\right)$ & Serum TAG $\left(\mathrm{mg}^{\mathrm{d}} \mathrm{dL}^{-1}\right)$ \\
\hline CDSO & $68.02 \pm 6.94$ & $26.35 \pm 3.11$ & $21.10 \pm 3.62^{\mathrm{a}, \mathrm{b}}$ & $198.59 \pm 7.07^{\mathrm{a}}$ \\
\hline DTCO & $68.24 \pm 4.23$ & $24.42 \pm 3.93$ & $15.75 \pm 1.92^{\mathrm{b}, \mathrm{c}}$ & $176.20 \pm 10.78^{\mathrm{a}, \mathrm{b}}$ \\
\hline HDPL & $77.50 \pm 8.63$ & $31.38 \pm 2.91$ & $32.13 \pm 3.97^{\mathrm{c}}$ & $215.52 \pm 6.88^{\mathrm{a}}$ \\
\hline $\mathrm{HDCO}$ & $58.32 \pm 6.50$ & $27.11 \pm 1.81$ & $22.30 \pm 3.10^{\mathrm{a}}$ & $111.85 \pm 4.85^{\mathrm{b}}$ \\
\hline
\end{tabular}

Results expressed as mean \pm standard deviation ( $\mathrm{n}=6$ /group). Different letters in the same column indicate significant difference according to Tukey test $(\mathrm{P}<0.05)$. CDSO: control diet AIN-93M (4\% soybean oil); DTCO: normolipidic diet (4\% coconut oil); HDPL: hyperlipidic diet $(4 \%$ soybean oil $+12 \%$ pork lard); HDCO: hyperlipidic diet $(4 \%$ coconut oil $+12 \%$ pork lard $)$; TC: total cholesterol; HDL: highdensity lipoprotein; LDL: low-density lipoprotein; TAG: triacylglycerol.

diets, where soybean oil was replaced with coconut oil, a $30.6 \%$ reduction in LDL was noted. For both normolipidic and hyperlipidic diets, replacing the oil resulted in decrease in serum TAG by $11.3 \%$ and $48.1 \%$, respectively, for DTCO and HDCO.

However, linoleic fatty acid (C18: 2n-6) predominant in soybean oil can lower HDL levels in the blood, which is considered a significant risk factor for cardiovascular diseases (NOAKES, 1998). This effect was not observed in the present study when comparing the use of soybean oil and extra virgin coconut oil. Increased serum HDL concentration is a protective factor against cardiovascular diseases, since it is associated with reverse cholesterol transport, and also against atherosclerosis (DORFMAN et al., 2005; ZAMBON et al., 2009).

As for the liver parameters, TC increased by $22.3 \%$ when using coconut oil in normolipidic diet, but when using coconut oil in hyperlipidic diets, the TC was $21.2 \%$ lower. A $13.5 \%$ increase in TAG was noted in normolipidic diets and a $26.7 \%$ reduction in hyperlipidic diets, when soybean oil was replaced with coconut oil (Table 3).

At the end of the experiment, it was observed that coconut oil significantly reduced $(\mathrm{P}<0.05)$ serum LDL and TAG, as well as the liver TC and TAG, both in normolipidic as well as in hyperlipidic diet. These effects may be the consequence of the amount and balance of fatty acids offered in the diets, especially since coconut oil contains an elevated amount of lauric acid.

The use of coconut oil is related to a decrease in serum TAG, since it contains high concentration of MCFAs, which are absorbed and transported through the portal vein to the liver where they are rapidly oxidized, generating energy. According to LIAU et al. (2011), MCFAs do not take part in the cholesterol cycle and are not accumulated in fat deposits.

A study by THOLSTRUP et al. (2004) compared diets rich in MCFA and LCFA and their effects on the lipid profile in humans, and the results showed an increase in the total plasma cholesterol, LDL-cholesterol, as well as HDL-cholesterol, when an MCFA-rich diet was provided.

NAGHII et al. (2012) assessed coconut oil as a supplement in rat diets, showing that, despite the high content in saturated fat, coconut oil seems to be beneficial for cardiovascular health, when consumed in moderation. However, the authors concluded that further studies are required to effectively indicate the use of coconut oil as a supplement.

Table 3 - Biochemical parameters evaluated in the liver of rats in rats after experimental use of extra virgin coconut oil $(n=6)$.

\begin{tabular}{lcc}
\hline Groups & Liver TC $\left(\mathrm{mg} \mathrm{dL}^{-1}\right)$ & Liver TAG $\left(\mathrm{mg} \mathrm{dL}^{-1}\right)$ \\
\hline CDSO & $37.42 \pm 1.08^{\mathrm{c}}$ & $251.61 \pm 5.19^{\mathrm{c}}$ \\
DTCO & $45.75 \pm 1.70^{\mathrm{c}}$ & $285.55 \pm 8.24^{\mathrm{b}}$ \\
HDPL & $80.87 \pm 0.79^{\mathrm{a}}$ & $352.05 \pm 6.75^{\mathrm{a}}$ \\
HDCO & $63.28 \pm 3.60^{\mathrm{b}}$ & $257.96 \pm 2.67^{\mathrm{c}}$ \\
\hline
\end{tabular}

Results expressed as mean \pm standard deviation ( $n=6 /$ group). Different letters in the same column indicate significant difference according to Tukey test $(\mathrm{P}<0.05)$. CDSO: control diet AIN-93M (4\% soybean oil); DTCO: normolipidic diet (4\% coconut oil); HDPL: hyperlipidic diet $(4 \%$ soybean oil $+12 \%$ pork lard); HDCO: hyperlipidic diet $(4 \%$ coconut oil $+12 \%$ pork lard $)$; TC: total cholesterol; TAG: triacylglycerol. 


\section{CONCLUSION}

Results obtained in the present study show that hyperlipidic diet leads to weight gain and increased accumulation of peritoneal fat. However, diet manipulation by substituting the lipid source in the hyperlipidic diet with extra virgin coconut oil instead of soybean oil resulted in lower accumulation of peritoneal and liver fat, as well as decreased levels of total cholesterol and triacylglycerols in the serum of the studied Wistar rats.

\section{ACKNOWLEDGEMENTS}

We acknowledge the financial support received from Coordenação de Aperfeiçoamento de Pessoal de Nível Superior (CAPES)/AUXPE and Fundação de Amparo à Pesquisa do Estado do Rio Grande do Sul (FAPERGS ARD) (process number 10/0489-0).

\section{REFERENCES}

ALMEIDA, M.E.F. et al. Serum lipids and hepatic morphology of rats fed diferente lipid source (soybean oil, fish fat and lard, margarine and butter). Revista de Nutrição, v.24, n.1, p.143-152, January/February 2011. Available from: <http://www.scielo.br/ pdf/rn/v24n1/v24n1a14>. Accessed: Nov. 12, 2014.

AMERICAN HEART ASSOCIATION (AHA) Scientific Statement. Dietary guidelines. Revision 2000. A statement for health care professionals from the nutrition committee of the American Heart Association. Circulation, v.102, n.18, p.2284-2299, 2000. Available from: <http://circ.ahajournals. org/content/102/18/2284.short>. Accessed: Sept. 02, 2014. doi: 10.1161/01.CIR.102.18.2284

ASAKURA, L. et al. Dietary medium-chain triacylglycerol prevents the postprandial rise of plasma triacylglycerols but induces hypercholesterolemia in primary hypertriglyceridemic subjects. American Journal of Clinical Nutrition, v.71, n.3, p.701-705, March 2000. Available from: <http://ajcn.nutrition.org/ content/71/3/701.short>. Accessed: Sept. 02, 2014.

ASSOCIATION OF OFFICIAL ANALYTICAL CHEMISTS Official methods of analysis of the AOAC International. 16 ed Washington: AOAC, 1995. $1230 \mathrm{p}$.

BAWALAN, D.D.; CHAPMAN K.R. Virgin coconut oil production manual for micro- and village - scale production. National Library, Bangkok Cataloguing-In-Publication data, February 2006. 80p. Available from: <ftp://ftp.fao.org/docrep/ fao/009/ag094e/ag094e00.pdf>. Accessed: Mar. 20, 2013.

BERNARDES, D. et al. Effects of high fat diet and swimming training of the recovery of metabolism during exercise in rats. Revista Brasileira de Educação Física e Esporte, v.18, n.2, p.191-200, April/June 2004. Available from: <http://www.revistas. usp.br/rbefe/article/view/16561/18274>. Accessed: Mar. 04, 2014. doi: $10.1590 / \mathrm{S} 1807-55092004000200007$.

BLIGH, E.G.; DYER, W.J. A rapid method of total lipid extraction and purification. Canadian Journal of Biochemistry and Physiology, v.37, n.8, p.911-917, August. 1959. Available from: <http://www.nrcresearchpress.com/doi/pdf/10.1139/o59-099>. Accessed: Apr. 06, 2013.

BRAZILIAN COLLEGE OF ANIMAL EXPERIMENTATION (COBEA). Ethical principles for animal experimentation. 2004. Available from: <http://www.cobea.org.br/>. Accessed: Apr. 01, 2013.

DEBMANDAL, M.; MANDAL S. Coconut (Cocos nucifera L.: Arecaceae): in health promotion and disease prevention. Asian Pacific Journal of Tropical Medicine, v.4, n.3, p.241-247, March 2011. Available from: <http://www.sciencedirect.com/science/ article/pii/S1995764511600783>. Accessed: Apr. 01, 2013. doi: 10.1016/ S1995764511600783.

DORFMAN, S.E. et al. Dietary fatty acids and cholesterol differentially modulate HDL cholesterol metabolism in GoldenSyrian hamsters. Journal of Nutrition, v.135, n.3 p.492-498, March 2005. Available from: <http://jn.nutrition.org/content/135/3/492. full.pdf + html $>$. Accessed: Apr. 01, 2013.

ESTADELLA, D. et al. Effect of palatable hyperlipidic diet on lipid metabolism of sedentary and exercised rats. Nutrition, v.20, n.2, p.218-224, February 2004. Available from: <http://www.ncbi. nlm.nih.gov/pubmed/14962690>. Accessed: Feb. 10, 2013.

FILHO, M.B.; RISSIN A. Nutritional transition in Brazil: geographic and temporal trends. Cadernos de Saúde Pública, v.19, sup.1, p.S181-S191, 2003. Available from: <http://www. scielo.br/pdf/csp/v19s1/a19v19s1.pdf>. Accessed: Apr. 10, 2013.

FRIEDEWALD, W.T. et al. Estimation of the concentration of low-density lipoprotein cholesterol in plasma, without use of the preparative ultracentrifuge. Clinical Chemistry, v.18, n.6, p.499-502, 1972. Available from: <http://www.clinchem.org/ content/36/1/15.full.pdf $>$. Accessed: Mar. 02, 2014.

KIM, E.M. et al. Effects of palatability-induced hyperphagia and food restriction on mRNA levels of neuropeptide $\mathrm{Y}$ in the arcuate nucleus. Brain Research, v.806, n.1, p.117-121, September 1998. Available from: $<$ http://www.sciencedirect.com/science/article/pii/ S0006899398007550>. Accessed: Mar. 02, 2014 doi: 10.1016/ S0006899398007550.

KRETSCHMER, B.D. et al. Modulatory role of food, feeding regime and physical exercise on body weight and insulin resistance. Life Science, v.76, n.14, p.1553-1573, February 2005. Available from: $<\mathrm{http}: / / \mathrm{www}$. sciencedirect.com/science/article/pii/ S0024320504010100>. Accessed: Mar. 02, 2014. doi: 10.1016/j. 1fs.2004.08.028.

KUMANYAKA S.K. Mini-symposium on obesity: overview and some strategic considerations. Annual Review of Public Health, v.22, p.293-308, May 2001. Available from: <http://www. annualreviews.org/doi/abs/10.1146/annurev.publhealth.22.1.293?j ournalCode $=$ publhealth $>$. Accessed: Mar. 02, 2014. doi: 10.1146/ annurev.publhealth.22.1.293.

LANGE, L.A. et al. Association of adipose tissue deposition and beta- 2 adrenergic receptor variants: the IRAS family study. International Journal of Obesity, v.29, p.449-457, January 2005. Available from: <http://www.nature.com/ijo/journal/v29/ n5/full/0802883a.html>. Accessed: Apr. 02, 2014. doi: 10.1038/ sj.ijo.0802883.

LIAU, K.M. et al. An open-label pilot study to assess the efficacy and safety of virgin coconut oil in reducing visceral adiposity. 
ISRN Pharmacology, v.1, p.1-7, March 2011. Available from: $<$ http://www.ncbi.nlm.nih.gov/pubmed/22164340>. Accessed: Apr. 02, 2014. doi: 10.5402/2011/949686.

MOURA, L.P.D. et al. Hepatic biochemical changes in rat submitted to a high-fat/high-energy diet. Revista de Nutrição, v.25, n.6, p.685-693, 2012. Available from: <http://www.scielo.br/scielo. php? script $=$ sci_arttext\&pid $=$ S 1415-52732012000600001\&lng $=$ en $\&$ nrm=iso $>$. Accessed: Jun. 08, 2013. doi: 10.1590/S141552732012000600001

NAGHII, M.R. et al. Effect of combination therapy of fatty acids, calcium, vitamin D and boron with regular physical activity on cardiovascular risk factors in rat. Journal of Oleo Science, v.61, n.2, p.103-111, 2012. Available from: <https://www.jstage.jst. go.jp/article/jos/61/2/61_2_103/_article>.Accessed: Jan. 10, 2014. doi: $10.5650 /$ jos.61.103.

NOAKES, M.; CLIFTON, P.M. Oil blends containing partially hydrogenated or interesterified fats: differential effects on plasma lipids. American Journal of Clinical Nutrition, v.68, n.2, p.242247, August 1998. Available from: <http://ajcn.nutrition.org/ content/68/2/242.full.pdf + html $>$. Accessed: Jan. 10, 2014.

OSCAI, L.B. et al. Effects of dietary sugar and of dietary fat on food intake and body fat content in rats. Growth, v.51, n.1, p.6473, 1987. Available from: <file://C:/Users/helbignt/Downloads/ Oscai.pdf $>$. Accessed: May 15, 2014.

PEREDA, J.A.O. et al. Tecnologia de alimentos. Componentes dos alimentos e processos. Porto Alegre: Artmed, 2005. 1v. 294p.
POPPITT, S.D. et al. Fatty acid chain length, postprandial satiety and food intake in lean men. Physiology \& Behavior, v.101, p.161-167, August 2010. Available from: <http://www.ncbi. nlm.nih.gov/pubmed/20451538>. Accessed: Mar. 10, 2014. doi: 10.1016/j.physbeh.2010.04.036.

REEVES, P.G. et al. AIN-93 purified diets for laboratory rodents: final report of the American Institute of Nutrition ad hoc writing committee on the reformulation of the AIN-76A rodent diet. Journal of Nutrition, v.123, p.1939-1951, November 1993. Available from: <http://jn.nutrition.org/content/123/11/1939. long>. Accessed: Mar. 22, 2013.

THOLSTRUP, T. et al. Effects of medium-chain fatty acids and oleic acid on blood lipids, lipoproteins, glucose, insulin, and lipid transfer protein activities. American Journal of Clinical Nutrition, v.79, n.4, p.564-569, April 2004. Available from: $<$ http://ajcn.nutrition.org/content/79/4/564.full $>$. Accessed: Mar. 22, 2014.

WHO. Diet, Nutrition and the prevention of chronic diseases: report of a joint WHO/FAO expert consultation. Geneva, 2003. (WHO technical report series: 916).

ZAMBON, L. et al. Effects of two different types of swimming exercise and adiposity and lipid profile in rats whit exogenous obesity. Revista de Nutrição, v.22, n.5, p.707715, 2009. Available from: <http://www.scielo.br/scielo. php?script $=$ sci_arttext\&pid $=$ S1415-52732009000500011\&lng $=$ en $\& n r m=$ iso $>$. Accessed: Jun. 08, 2013. doi: 10.1590/S141552732009000500011 . 